\title{
Multidisciplinary approach to patients with manifestations and pulmonary complications of cystic fibrosis
}

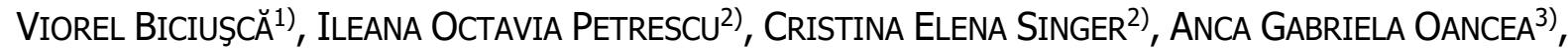 \\ Ana-Maria PetresCu4), Ionelia-Sorina Stan ${ }^{5}$, Patricia Durand ${ }^{5)}$, Citto IUlian TAISESCU6), \\ DANIELA DUMITRESCU7), MIHAELA AMELIA DOBRESCU ${ }^{8)}$, ION UDRIŞTOIU ${ }^{9}$, \\ DiANA RODICA TUDORAŞCU ${ }^{10}$, FLORIN PETRESCU ${ }^{10)}$
}

\begin{abstract}
1) Department of Internal Medicine, Faculty of Medicine, University of Medicine and Pharmacy of Craiova, Romania
2) Department of Pediatrics, Faculty of Medicine, University of Medicine and Pharmacy of Craiova, Romania

3) Department of Pediatrics, Emergency County Hospital, Craiova, Romania

4) Department of Obstetrics and Gynecology, Resident Physician, Emergency County Hospital, Craiova, Romania

5) Department of Internal Medicine, Resident Physician, Emergency County Hospital, Craiova, Romania

${ }^{6)}$ Department of Physiology, Faculty of Medicine, University of Medicine and Pharmacy of Craiova, Romania

7) Department of Radiology and Medical Imaging, University of Medicine and Pharmacy of Craiova, Romania

8) Department of Medical Genetics, Faculty of Medicine, University of Medicine and Pharmacy of Craiova, Romania

9) Department of Psychiatry, Faculty of Medicine, University of Medicine and Pharmacy of Craiova, Romania

${ }^{10)}$ Department of Medical Semiology, Faculty of Medicine, University of Medicine and Pharmacy of Craiova, Romania
\end{abstract}

\begin{abstract}
Cystic fibrosis (CF) is a genetic disease, with autosomal recessive transmission, multisystemic, characterized by a remarkable clinical polymorphism and significant lethal prospective. Respiratory manifestations dominate the clinical picture, being present in all patients. The aim of the paper was to analyze the incidence of clinical manifestations, especially respiratory ones, as well as the contribution of interdisciplinary consultations to the positive diagnosis of $\mathrm{CF}$, in a group of 16 patients who were hospitalized and treated in the IInd Pediatric Clinic and IInd Medical Clinic of the Emergency County Hospital, Craiova, Romania, in a period of 20 years. The 16 patients diagnosed with and treated of CF had all shown increased values of sweat chloride concentration of over $60 \mathrm{mmol} / \mathrm{L}$. The main symptoms and clinical signs encountered in these patients were cough $(75 \%)$, sputum $(62.5 \%)$, dyspnea $(50 \%)$, wheezing $(50 \%)$, stature hypotrophy $(100 \%)$, pallor $(37.5 \%)$, cyanosis $(25 \%)$. All 16 patients had an acute exacerbation of chronic pulmonary disease. Of the total hospitalizations, the death was recorded only in the case of one female patient. The association of some clinical aspects specific with a positive result of the sweat test or the presence of the two pathological alleles made room for determining a positive diagnosis. The multisystemic nature of this disease requires a multidisciplinary approach to these patients. Histopathologically, there was a correspondence between lung morphological lesions and the results of imaging investigations.
\end{abstract}

Keywords: cystic fibrosis, genetic disease, pulmonary manifestations, multisystemic approach.

\section{口 Introduction}

Cystic fibrosis $(\mathrm{CF})$ is an inherited autosomal recessive disorder, with a significant clinical heterogeneity, that requires from a complex treatment [1]. In Romania, the frequency of the disease is estimated in approximately one in 2500 newborns, with a prevalence of about 1.5 cases per 100000 inhabitants and a carrier frequency (heterozygotes) of one in 25 [2]. The disease is caused by mutations in the cystic fibrosis transmembrane conductance regulator (CFTR) gene located on the long arm of chromosome 7 ( $7 \mathrm{q} 31)$, which encodes a transmembrane conductance regulator protein, CFTR, acting as a chloride channel at the apical membrane of epithelial cells [3]. The phenotypic features result from the absence or inappropriate function of the chloride channels at the cellular level, which involves the presence of viscous secretions adherent to the epithelium of the excretory ducts difficult to discharge as well as to their accumulation and the alteration of the function and destruction of various organs (lungs, pancreas, liver, intestine, and reproductive organs) [4]. The diagnosis of CF is based on specific clinical symptoms and anamnestic data and then it is confirmed by the sweat test or the molecular genetic testing [5].

A CF test must be conducted for every child presenting with severe respiratory distress associated with a chronic pulmonary disease (chronic cough, mucopurulent or purulent sputum, expiratory dyspnea, wheezing, pulmonary hyperinflation) or a bronchial obstruction with modified values in the spirometry tests, specific circumstances for a persistent pulmonary colonization with Staphylococcus aureus and Pseudomonas aeruginosa, persistent pulmonary radiological modifications, nasal polyposis, sinusitis or chronic ethmoiditis [6], but can be found and associated with common gastrointestinal and nutritional manifestations: meconium ileus, rectal prolapse, pancreatic insufficiency with malabsorption and steatorrhea, recurrent acute pancreatitis or chronic

This is an open-access article distributed under the terms of a Creative Commons Attribution-NonCommercial-ShareAlike 4.0 International Public License, which permits unrestricted use, adaptation, distribution and reproduction in any medium, non-commercially, provided the new creations are licensed under identical terms as the original work and the original work is properly cited. 
pancreatitis, persistent neonatal jaundice, distal intestinal obstruction syndrome, chronic hepatopathy clinically and biologically manifested or on ultrasonographic and/or histological assessment by having the aspect of a focal or lobular biliary cirrhosis, protein-calorie malnutrition resulting in hypoproteinemic edema, as well as secondary complications to liposoluble vitamin deficiency (skin or mucous membrane hemorrhages, rickets, and nocturnal cecity) [7].

There are other specific manifestations of this disease such as salt-wasting syndrome, hypochloremic metabolic alkalosis with hyponatremic dehydration, increased levels of serum trypsinogen in newborn screening and obstructive azoospermia in case of congenital absence of vas deferens [8].

The diagnosis of CF can be determined in the presence of one or multiple phenotypic traits of the above-mentioned $\mathrm{CF}$, in a patient that have the proof of the abnormal function of CFTR by detecting two abnormal values of sweat $\mathrm{Cl}^{-}$by quantitative pilocarpine iontophoresis test or identification of diallelic CFTR pathogenic variants [9]. The sweat test remains the gold standard test for diagnosing the disease and assessing the concentrations of $\mathrm{Cl}^{-}$and $\mathrm{Na}^{+}$ions in the sweat. A sweat $\mathrm{Cl}^{-}$concentration greater than $60 \mathrm{mmol} / \mathrm{L}$, in two different assessments, can determine the correct diagnosis [10]. Molecular genetic testing approaches CFTR mutation panel that includes the most common pathogenic variants followed by extended CFTR gene sequencing and evaluation for deletions or duplications if only one or no pathogenic variant is found [11]. The diagnostic role of histopathological (HP) investigations was secondary, confirming the morphological substrate of the clinical picture in patients who die during hospitalization.

\section{Aim}

The aim of the paper is to demonstrate that due to the multisystemic nature of this disease, a multidisciplinary approach of patients is required, in order to early diagnose the complications of the disease and administer appropriate therapy, so as to increase quality of life and survival.

\section{口 Patients, Materials and Methods}

We have realized a retrospective clinical study of 16 patients who were hospitalized and diagnosed with $\mathrm{CF}$ in the II ${ }^{\text {nd }}$ Pediatric Clinic and II $^{\text {nd }}$ Medical Clinic of the Emergency County Hospital, Craiova, Romania, from 2000 to 2020. The diagnosis of CF was achieved based on the anamnesis and the clinical evaluation of children, correlated with the paraclinical investigations in infants and children and confirmed by the sweat test or genetic testing of these patients. Patients were included in the study group according to high levels of $\mathrm{Cl}^{-}$ions concentration in the sweat after stimulating it with quantitative pilocarpine (a sweat $\mathrm{Cl}^{-}$concentration greater than $60 \mathrm{mmol} / \mathrm{L}$ ). The sweat test measures the concentration of $\mathrm{Cl}^{-}$and $\mathrm{Na}^{+}$ions in the sweat test. A sweat $\mathrm{Cl}^{-}$concentration greater than $60 \mathrm{mmol} / \mathrm{L}$, in two different assessments, confirmed the diagnosis. When a patient with hyponatremia and hypochloremia is clinically suspected of having $\mathrm{CF}$, the sweat test was delayed until an electrolytic balance has been restored. The normal values of electrolytes in sweat are less than $40 \mathrm{mmol} / \mathrm{L}$. Positive values were observed in children $>60 \mathrm{mmol} / \mathrm{L}$, while adolescents and teenagers registered $>70 \mathrm{mmol} / \mathrm{L}$; values considered equivocal, between 40 and $60 \mathrm{mmol} / \mathrm{L}$ required repeating the investigation after a while. Genetic testing was performed in two Genetics Laboratories (Bucharest and Timişoara). Peripheral blood samples were collected from each child testing positive for the sweat test and for healthy controls, in ethylenediaminetetraacetic acid (EDTA) tubes. The deoxyribonucleic acid (DNA) extraction was performed by QIAmp DNA Blood Mini Kit (QIAGEN). All samples (patients and controls) were analyzed for the 29 common mutations by Elucigene ${ }^{\mathrm{TM}}$ CF29 multiplex ARMS kit (Tepnel Diagnostics Ltd, UK), as a rapid screening according to the manufacturer's instructions. To evaluate the frequency of the $5 T$ allele of intron 8 , amplification and sequencing of the polypyrimidine tract in front of exon 9 was performed using primers 9i-5 and 9i-3 [12]. Imagistic investigations (radiography, tomography, ultrasound exam) were made with the equipment used by the Laboratory of Radiology and Medical Imaging, Emergency County Hospital of Craiova. Laboratory from samples involving hematology, biochemistry, immunology, bacteriology, and gasometric methods) were done in the Clinical Laboratory of the Hospital, using the system known as Celltac Nihon Khoden and Vitros 250 dry chemistry analyzers. The HP investigations were performed on the specimens harvested from the patient who died because of the evolution of this disease. The necropsy fragments of the lungs were processed by the classic histological technique with 24 hours routine $4 \%$ neutral buffered formalin fixation, and paraffin embedding in the Laboratory of Pathology from the Emergency County Hospital of Craiova. Four $\mu \mathrm{m}$-thick sections from the resulting paraffin blocks were cut at the microtome, and then stained with Hematoxylin-Eosin (HE). The stained sections were examined under a Nikon Eclipse 55i microscope by two pathologists highlighting the lesions characteristic of CF. The statistical analysis was performed using the Microsoft Excel (Microsoft Corp., Redmond, WA, USA), together with the XLSTAT add-on for MS Excel (Addinsoft SARL, Paris, France) and IBM Statistical Package for the Social Sciences (SPSS) Statistics 20.0 (IBM Corporation, Armonk, NY, USA) for data processing. Because the numerical variables investigated had a normal data distribution, globally or in each studied group, we were allowed to use the parametric statistical tests (e.g., Student's $t$-test) and the results were summarized as the mean value \pm standard deviation (SD). For all statistical tests, $p$-values less than 0.05 were considered significant. All imagistic, hematological, biochemical, immunological, bacteriological, functional, and genetic investigations were made after obtaining the informed consent from the tutor of the hospitalized child or the diagnosed teenager, which guarantees the fundamental rights of the patient.

\section{ㅁ Results}

The 16 patients suffering from CF (13 children and three adults) diagnosed and treated in the Emergency County Hospital of Craiova, from 2000 to 2020. Patients were between four and 27 years old, with an average age of $12.31 \pm 6.27$ years. Most patients were male, 12 (75\%) patients, while the minority was female, four $(25 \%)$ patients. 
The patients included in the study came from Oltenia Region, as follows: 10 (62.5\%) patients from Dolj County, four $(25 \%)$ patients from Olt County, and two (12.5\%) patients from Vâlcea County. The age of mothers when they gave birth was between 22 and 31 years old, with an average age of $25.42 \pm 5.74$ years. The outstanding family antecedents of the patients were found in the brother's case who manifested CF in two (12.5\%) cases. The kids showed first symptoms at an age between one day and seven months of life, with an average age of debut of $3.088 \pm 2.87$ months. The symptoms of debut were respiratory symptoms in four $(25 \%)$ patients, digestive signs and symptoms in six $(37.5 \%)$ patients or association of wheezing with chronic diarrhea in four (25\%) patients, and retarded growth associated with coughing and diarrhea in two $(12.5 \%)$ patients. The average age of the patients at the time of diagnosis was $3.63 \pm 2.72$ years, with limits between 0 and 12 years. The average body mass index (BMI) value was $14.24 \pm 1.65 \mathrm{~kg} / \mathrm{m}^{2}$, with limits between 12.26 and $16.49 \mathrm{~kg} / \mathrm{m}^{2}$.

Clinical manifestations among CF patients hospitalized and under treatment are shown in the Table 1.

Table 1 - Incidence of clinical manifestations

\begin{tabular}{cccc}
\hline Symptoms & $\begin{array}{c}\text { No. of patients/ } \\
\text { incidence (\%) }\end{array}$ & $\begin{array}{c}\text { Clinical } \\
\text { signs }\end{array}$ & $\begin{array}{c}\text { No. of patients/ } \\
\text { incidence (\%) }\end{array}$ \\
\hline Cough & $12(75 \%)$ & $\begin{array}{c}\text { Stature } \\
\text { hypotrophy }\end{array}$ & $16(100 \%)$ \\
\hline Expectoration & $10(62.5 \%)$ & Paleness & $6(37.5 \%)$ \\
\hline Dyspnea & $8(50 \%)$ & Cyanosis & $4(25 \%)$ \\
\hline Wheezing & $8(50 \%)$ & Jaundice & $2(12.5 \%)$ \\
\hline Fever & $8(50 \%)$ & $\begin{array}{c}\text { Persistent skin } \\
\text { crease }\end{array}$ & $8(50 \%)$ \\
\hline Diarrhea & $10(67.5 \%)$ & Clubbing fingers & $3(18.75 \%)$ \\
\hline Constipation & $2(12.5 \%)$ & Orthopnea & $2(12.5 \%)$ \\
\hline $\begin{array}{c}\text { Loss of } \\
\text { appetite }\end{array}$ & $8(50 \%)$ & $\begin{array}{c}\text { Bronchial } \\
\text { rales }\end{array}$ & $4(25 \%)$ \\
\hline Weight loss & $12(75 \%)$ & $\begin{array}{c}\text { Bronchoalveolar } \\
\text { rales }\end{array}$ & $2(12.5 \%)$ \\
\hline Abdominal & $6(37.5 \%)$ & $\begin{array}{c}\text { Abdominal } \\
\text { distension }\end{array}$ & $1062.5 \%)$ \\
\hline pain & $4(25 \%)$ & Hepatomegaly & $4(25 \%)$ \\
\hline Vomiting & $2(12.5 \%)$ & Splenomegaly & $2(12.5 \%)$ \\
\hline Oliguria & $8(50 \%)$ & $\begin{array}{c}\text { Alteration of } \\
\text { consciousness }\end{array}$ & $1(6.25 \%)$ \\
\hline
\end{tabular}

All 16 patients had exacerbations of chronic bronchopulmonary disease. The number of infectious exacerbations registered in these patients was 49 per year, with an average value of $3.06 \pm 0.46$ acute symptoms/patient/year. The total number of hospitalizations of the patients included in the present study per year was 67 , which represents an average value of $4.18 \pm 1.24$ hospitalizations/patient/year. There was only one reported death, a 10-year-old girl, whose leading cause of death was a cardiorespiratory arrest resulting from a staphylococcal pneumonia with acute chronic respiratory failure. All hospitalized patients showed high levels of $\mathrm{Cl}^{-}$concentration in the sweat test, over $60 \mathrm{mmol} / \mathrm{L}$, the average value registered with these patients being $114.75 \pm 18.07 \mathrm{mmol} / \mathrm{L}$, with limits between 80 and $193 \mathrm{mmol} / \mathrm{L}$ in the sweat test. Genetic analysis was performed on DNA samples obtained from $14(87.5 \%)$ patients. Two mutations were found in all patients. Six different CFTR mutations were detected: $\triangle F 508$ at 18 (53.57\%) out of 28 CFTR alleles tested, $N 1303 \mathrm{~K}$ at four
(14.28\%) out of 28 CFTR alleles, G85E at three (10.71\%) out of 28 CFTR alleles, 394delTT and 2184 delA in only one (3.57\%) out of 28 CFTR alleles and 5T polymorphism in one $(3.57 \%)$ patient. Most patients, nine $(56.25 \%)$ out of 14 patients, were compound heterozygous, and five (31.25\%) were homozygous. In other two patients, who did not undergo genetic testing, the sweat test was used to help diagnose $\mathrm{CF}$.

Modifications present in pulmonary radiography and computed tomography (CT) are shown in the Table 2.

Table 2 - Incidence of imagistic examination modifications

\begin{tabular}{cccc}
\hline $\begin{array}{c}\text { Radiological } \\
\text { features } \\
\text { (16 patients) }\end{array}$ & $\begin{array}{c}\text { No. of } \\
\text { patients/ } \\
\text { incidence } \\
\text { (\%) }\end{array}$ & $\begin{array}{c}\text { CT features } \\
\text { (five from 16 } \\
\text { patients) }\end{array}$ & $\begin{array}{c}\text { No. of } \\
\text { patients/ } \\
\text { incidence } \\
\text { (\%) }\end{array}$ \\
\hline $\begin{array}{c}\text { Accentuation of the } \\
\text { peribronchovascular } \\
\text { pulmonary } \\
\text { interstitium }\end{array}$ & $\begin{array}{c}12 / 16 \\
(75 \%)\end{array}$ & $\begin{array}{c}\text { Bronchiectasis of } \\
\text { bilateral upper } \\
\text { lobes }\end{array}$ & $\begin{array}{c}3 / 5 \\
(60 \%)\end{array}$ \\
\hline $\begin{array}{c}\text { Apical bilateral } \\
\text { bronchial } \\
\text { dilatations }\end{array}$ & $\begin{array}{c}4 / 16 \\
(25 \%)\end{array}$ & $\begin{array}{c}\text { Disseminated } \\
\text { bronchiectasis } \\
\text { of both lungs }\end{array}$ & $\begin{array}{c}2 / 5 \\
(40 \%)\end{array}$ \\
\hline $\begin{array}{c}\text { Pulmonary opacity } \\
\text { with the appearance } \\
\text { of pulmonary } \\
\text { condensation }\end{array}$ & $\begin{array}{c}2 / 16 \\
(12.5 \%)\end{array}$ & $\begin{array}{c}\text { Peribronchovascular } \\
\text { interstitial pulmonary } \\
\text { fibrosis }\end{array}$ & $\begin{array}{c}5 / 5 \\
(100 \%)\end{array}$ \\
\hline $\begin{array}{c}\text { Pulmonary } \\
\text { hyperinflation }\end{array}$ & $\begin{array}{c}2 / 16 \\
(12.5 \%)\end{array}$ & $\begin{array}{c}\text { Pneumonic-type } \\
\text { condensation }\end{array}$ & $\begin{array}{c}2 / 5 \\
(40 \%)\end{array}$ \\
\hline $\begin{array}{c}\text { Normal lung } \\
\text { radiograph } \\
\text { appearance }\end{array}$ & $\begin{array}{c}2 / 16 \\
(12.5 \%)\end{array}$ & Lung distention & $\begin{array}{c}1 / 5 \\
(20 \%)\end{array}$ \\
\hline
\end{tabular}

$\mathrm{CT}$ : Computed tomography.

On chest radiographs, the earliest modification was accentuation of the peribronchovascular pulmonary interstitium (Figure 1).

On CT images, the most common changes were lung hyperinflation, pulmonary hypertension, and bronchiectasis (Figures 2 and 3).

Spirometry was performed for 12 patients and allowed for a registered forced vital capacity, both with an absolute and a relative (percentage) value, the forced expiratory volume in the first second (FEV1) and the index of bronchial permeability. Low values of forced vital capacity (FVC) were registered in the investigated patients, less than $80 \%$ of standard values were calculated in three $(25 \%)$ patients, low levels of FEV1 were less than $80 \%$ of standard values calculated in five (41.66\%) patients, low levels of the index of bronchial permeability less than $70 \%$ in three (25\%) patients. Germs involved in the production of infectious exacerbations (identified in pathological products of tracheobronchial tree), which complicated the evolution of the disease, were: Methicillin-sensitive $S$. aureus (MSSA) $20(40.81 \%)$ infectious episodes, $P$. aeruginosa 12 (24.48\%) infectious episodes, Methicillin-resistant $S$. aureus (MRSA) six (12.24\%) infectious episodes, Klebsiella pneumoniae four $(8.16 \%)$ infectious episodes, Burkholderia cepacia two $(4.08 \%)$ infectious episodes, and Serratia liquefaciens one infectious episode (2.04\%). There were four $(7.27 \%)$ mixed infectious episodes with $P$. aeruginosa and MRSA.

The average, minimum and maximum values of hematological and biochemical parameters are shown in the Table 3 .

The average, minimum and maximum values of liver and pancreatic laboratory tests are shown in the Table 4 . 

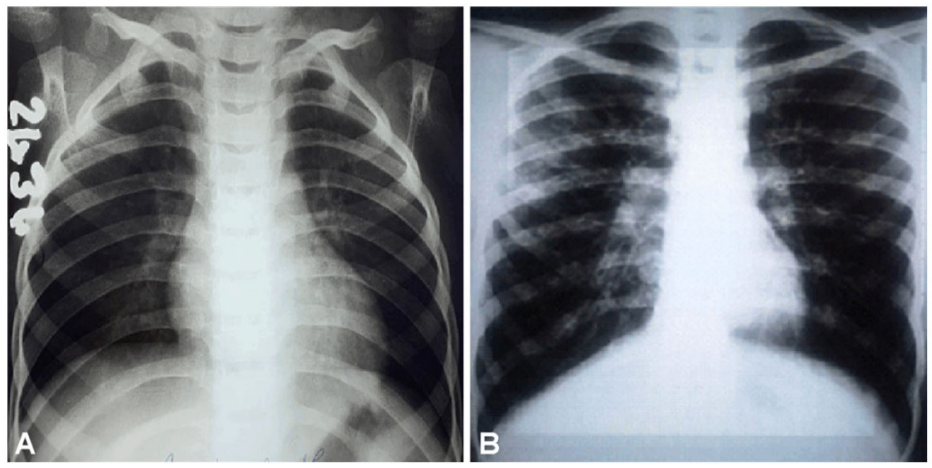

Figure 1 - Radiological aspects in CF. Chest radiographs in postero-anterior incidence. (A) Fouryear-old child diagnosed with CF. Pulmonary hyperinflation. Pulmonary hypertension - vascular enlargement of pulmonary hilum. Accentuation of the apical and perihilar pulmonary interstitium, bilateral. (B) Eighteen-year-old adolescent with $C F$. Pulmonary hyperinflation. Pulmonary hypertension - vascular enlargement of pulmonary hilum. Bronchial dilatations with a predominant cylindrical appearance, in the upper half of the bilateral lung areas. CF: Cystic fibrosis.

Figure 2 - CT scans in CF. Axial CT images. (A) Pulmonary hyperinflation. Pulmonary hypertension vascular enlargement of pulmonary hilum. Bronchi with thickened walls. Cylindrical bronchiectasis (1).

(B) Cystic dilated bronchi (1) in an 18-year-old adolescent patient. The "signet ring of bronchiectasis" (2), with the cystic dilated bronchus representing the "ring" and the adjacent smaller artery representing the "jewel" on the ring. CT:

Computed tomography; CF: Cystic fibrosis.
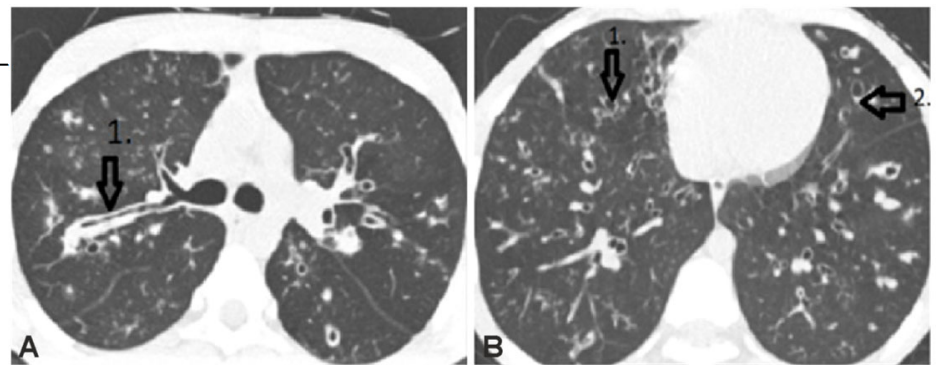

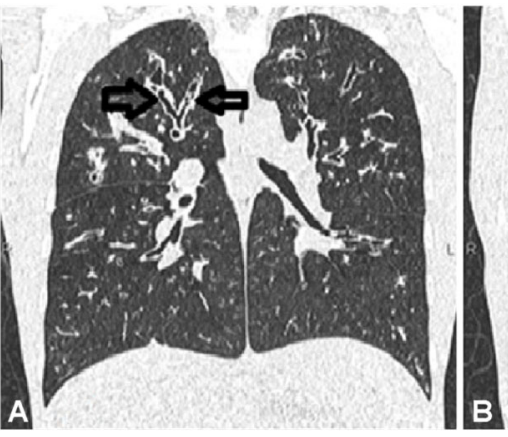

Table 3 - The average, minimum and maximum values of the hematological and biochemical parameters

\begin{tabular}{|c|c|c|c|}
\hline Parameter & $\begin{array}{c}\text { Average value, } \\
\text { minimum and } \\
\text { maximum } \\
\text { values }\end{array}$ & Parameter & $\begin{array}{c}\text { Average value, } \\
\text { minimum and } \\
\text { maximum } \\
\text { values }\end{array}$ \\
\hline $\mathrm{Hb}[\mathrm{g} / \mathrm{dL}]$ & $\begin{array}{l}11.43 \pm 3.43 \\
(7.7-14.5)\end{array}$ & $y$-Globulin [g\%] & $\begin{array}{c}15.87 \pm 6.91 \\
(6-34)\end{array}$ \\
\hline MEV [fL] & $\begin{array}{c}83.8 \pm 14.68 \\
(66-105)\end{array}$ & $\mathrm{pH}$ & $\begin{array}{c}7.42 \pm 0.05 \\
(7.35-7.51)\end{array}$ \\
\hline $\mathrm{MCH}[\mathrm{pg} / \mathrm{mL}]$ & $\begin{array}{c}25.4 \pm 3.51 \\
(20-29)\end{array}$ & $\mathrm{PaO} 2$ [mmHg] & $\begin{array}{c}72.8 \pm 22.88 \\
(37-99)\end{array}$ \\
\hline $\begin{array}{l}\text { Leukocyte } \\
\text { count }\left[/ \mathrm{mm}^{3}\right]\end{array}$ & $\begin{array}{c}11550.63 \pm \\
5290.67 \\
(7500-28000)\end{array}$ & $\mathrm{PaCO} 2[\mathrm{mmHg}]$ & $\begin{array}{c}33.6 \pm 5.22 \\
(27-36)\end{array}$ \\
\hline $\begin{array}{c}\text { Platelet } \\
\text { count }\left[/ \mathrm{mm}^{3}\right]\end{array}$ & $\begin{array}{c}387540.43 \pm \\
112400.62 \\
(180000- \\
540000) \\
\end{array}$ & $\mathrm{HCO}_{3}{ }^{-}[\mathrm{mEq} / \mathrm{L}]$ & $\begin{array}{c}33.6 \pm 5.22 \\
(27-36)\end{array}$ \\
\hline $\mathrm{Fe}[\mu \mathrm{g} / \mathrm{dL}]$ & $\begin{array}{c}48.5 \pm 22.98 \\
(12-113)\end{array}$ & D-dimers $[\mu \mathrm{g} / \mathrm{mL}]$ & $\begin{array}{l}1.24 \pm 0.48 \\
(0.5-1.8)\end{array}$ \\
\hline $\mathrm{ESR}[\mathrm{mm} / 1 \mathrm{~h}]$ & $\begin{array}{c}26.56 \pm 11.07 \\
(5-52)\end{array}$ & $\begin{array}{l}\text { NT-proBNP } \\
{[\mathrm{pg} / \mathrm{mL}]}\end{array}$ & $\begin{array}{c}54.42 \pm 23.45 \\
(30-120)\end{array}$ \\
\hline $\mathrm{Fb}[\mathrm{mg} / \mathrm{dL}]$ & $\begin{array}{c}435.07 \pm 113.14 \\
(250-750)\end{array}$ & Urea [mg/dL] & $\begin{array}{c}28.5 \pm 14.45 \\
(13-98) \\
\end{array}$ \\
\hline CRP [mg/L] & $\begin{array}{c}2.975 \pm 1.78 \\
(0.3-9)\end{array}$ & Uric acid [mg/dL] & $\begin{array}{c}0.46 \pm 0.12 \\
(0.3-0.9)\end{array}$ \\
\hline
\end{tabular}

$\mathrm{Hb}$ : Hemoglobin; MEV: Mean erythrocyte volume; $\mathrm{MCH}$ : Mean corpuscular hemoglobin; Fe: Serum iron; ESR: Erythrocyte sedimentation rate; Fb: Fibrinogen; CRP: C-reactive protein; $\mathrm{PaO} 2$ Partial pressure of oxygen; $\mathrm{PaCO} 2$ : Partial pressure of carbon dioxide; $\mathrm{HCO}_{3}^{-}$: Serum bicarbonate; NT-proBNP: $\mathrm{N}$-terminal probrain natriuretic peptide.
Table 4 - The average, minimum and maximum values of liver and pancreatic laboratory tests

\begin{tabular}{cccc}
\hline Parameter & $\begin{array}{c}\text { Average value, } \\
\text { minimum and } \\
\text { maximum } \\
\text { values }\end{array}$ & Parameter & $\begin{array}{c}\text { Average value, } \\
\text { minimum and } \\
\text { maximum } \\
\text { values }\end{array}$ \\
\hline TBIL [mg\%] & $\begin{array}{c}1.31 \pm 1.13 \\
(0.5-6.8)\end{array}$ & $\mathrm{Am}[\mathrm{U} / \mathrm{L}]$ & $\begin{array}{c}42.8 \pm 28.72 \\
(20-97)\end{array}$ \\
\hline DBIL [mg\%] & $\begin{array}{c}0.63 \pm 0.37 \\
(0.2-2.73)\end{array}$ & $\mathrm{Lip}[\mathrm{U} / \mathrm{L}]$ & $\begin{array}{c}30.66 \pm 10.14 \\
(23-45)\end{array}$ \\
\hline ALP [U/L] & $\begin{array}{c}286.46 \pm 148.76 \\
(125-576)\end{array}$ & $\mathrm{Ca}[\mathrm{mg} / \mathrm{dL}]$ & $\begin{array}{c}8.36 \pm 0.84 \\
(7.4-10.6)\end{array}$ \\
\hline GGT [U/L] & $\begin{array}{c}77.78 \pm 14.06 \\
(12-477)\end{array}$ & $\mathrm{Ca}^{2+}[\mathrm{mg} / \mathrm{dL}]$ & $\begin{array}{c}3.32 \pm 0.78 \\
(1.2-4.4)\end{array}$ \\
\hline ALT [U/L] & $\begin{array}{c}42.5 \pm 28.55 \\
(13-100)\end{array}$ & $\mathrm{Mg}[\mathrm{mg} / \mathrm{dL}]$ & $\begin{array}{c}1.75 \pm 0.26 \\
(1.4-2.1)\end{array}$ \\
\hline AST [U/L] & $\begin{array}{c}42.8 \pm 28.72 \\
(20-197)\end{array}$ & $\mathrm{VitD} 3[\mathrm{U} / \mathrm{L}]$ & $\begin{array}{c}38.8 \pm 13.91 \\
(24-54)\end{array}$ \\
\hline TP [g\%] & $\begin{array}{c}6.29 \pm 1.35 \\
(4.4-9.5)\end{array}$ & $\mathrm{Na}[\mathrm{mEq} / \mathrm{dL}]$ & $\begin{array}{c}130.22 \pm 8.8 \\
(118-137)\end{array}$ \\
\hline S-alb [g\%] & $\begin{array}{c}3.72 \pm 0.65 \\
(2.9-4.8)\end{array}$ & $\mathrm{K}[\mathrm{mEq} / \mathrm{dL}]$ & $\begin{array}{c}4.3 \pm 0.9 \\
(3.1-5.1)\end{array}$ \\
\hline PT [\%] & $\begin{array}{c}77.93 \pm 11.66 \\
(68-100)\end{array}$ & $\mathrm{Cl}[\mathrm{mEq} / \mathrm{dL}]$ & $\begin{array}{c}95.87 \pm 9.94 \\
(76-104)\end{array}$ \\
\hline
\end{tabular}

TBIL: Total bilirubin; DBIL: Direct bilirubin; ALP: Alkaline phosphatase; GGT: Gamma-glutamyltransferase; ALT: Alanine transaminase; AST: Aspartate transaminase; TP: Total proteins; S-alb: Serum albumin; PT: Prothrombin time; Am: Amylasemia; Lip: Lipasemia; Ca: Serum calcium; $\mathrm{Ca}^{2+}$ : Ionized calcium; Mg: Magnesium; VitD3: Vitamin D3; Na: Sodium; K: Potassium; Cl: Chloride.

The modifications resulted from the stool test were as follows: presence of drops of undigested fats in eight (50\%) 
patients, presence of undigested fat drops and muscular fibers in four $(25 \%)$ patients, presence of fat drops and undigested starch in three (18.75\%) patients. The average value of the fecal pancreatic elastase performed on six patients was $78.42 \pm 43.36$, with limits between $29-100 \mathrm{mg} / \mathrm{dL}$. Abdominal ultrasound exam performed on the tested patients revealed: hepatomegaly in four $(25 \%)$ patients, modifications of hepatic echogenicity in six $(37.5 \%)$ patients, modifications of hepatic structure in six (37.5\%) patients, modifications of hepatic contour in one $(6.25 \%)$ patient, caudate lobe hypertrophy in one $(6.25 \%)$ patient, increase in portal vein diameter in one $(6.25 \%)$ patient, splenomegaly in three $(18.75 \%)$ patients and an increase in the splenic vein diameter in one $(6.25 \%)$ patient. The endocrinology exam performed on these children confirmed the following results: postural hypotrophy in $16(100 \%)$ patients, osteopenia in four $(25 \%)$ patients, and delayed menarche in two $(12.5 \%)$ patients. The ear, nose, and throat (ENT) exam performed on most hospitalized patients

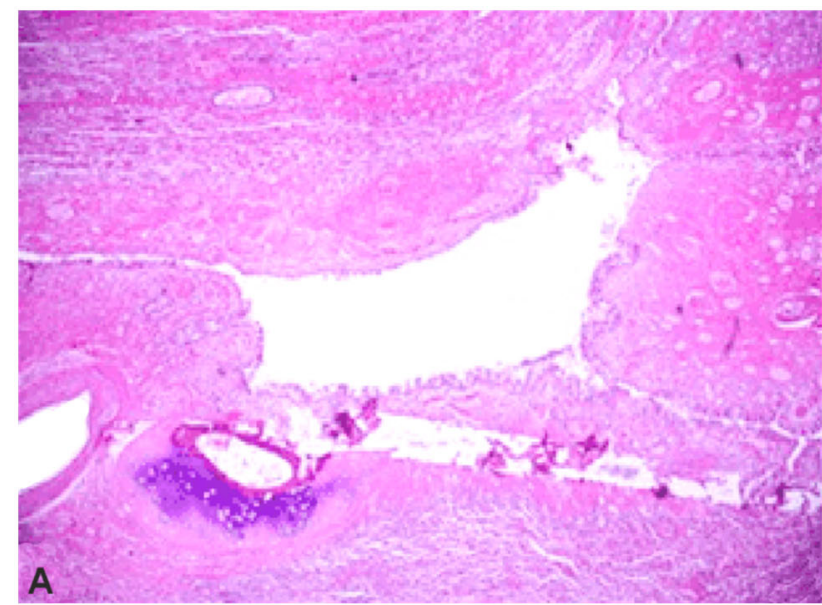

described acute nasopharyngitis in four $(25 \%)$ patients, acute tonsillitis in four $(25 \%)$ patients, nasal polyposis in four $(25 \%)$ patients, acute otitis in three $(18.75 \%)$ patients, acute rhino-adenoiditis in two (12.5\%) patients, chronic tonsillitis in six $(37.5 \%)$ patients, and chronic rhinosinusitis in four $(25 \%)$ patients.

HP examination of pulmonary necropsy fragments revealed the presence of a large lesion diversity. Thus, the predominant lesions have been hypertrophy of the bronchial glands, mucous cell hyperplasia of the trachea and main bronchi (Figure 4A), the presence of intraluminal mucous plugs, acute and chronic inflammation of bronchi, with the presence of mucopurulent exudate with microbial colonization in the lumen of lower respiratory airways and the presence of a diverse inflammatory cell population with neutrophils, histiocytes, lymphocytes, and plasma cells (Figure 4B). Others associated lesions were the ulcerations of the bronchial and bronchiolar mucosa, endobronchial abscesses, bronchiectasis, and atelectasis.

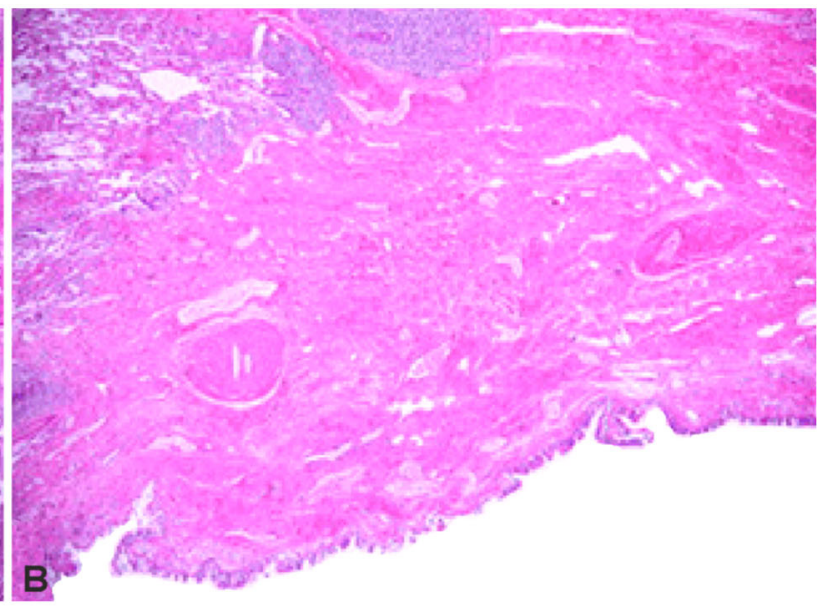

Figure 4 - Lung necropsy fragments (HE staining, $\times 40)$ : (A) A main bronchus with mucous cell hyperplasia, mucous gland hypertrophy, fibrosis predominantly in the submucosa and in the intima of the pulmonary arterial branches; (B) A bronchiole with ulcerated areas of the epithelium, extensive fibrosis starting from the basement membrane of the bronchial epithelium and extending into the pulmonary interstitium associated with fibrosis in the intima and hypertrophy of the middle layer of the branches of the pulmonary artery. HE: Hematoxylin-Eosin.

\section{口 Discussions}

Amongst the patients hospitalized in the II ${ }^{\text {nd }}$ Pediatric Clinic and II ${ }^{\text {nd }}$ Medical Clinic of the Emergency County Hospital of Craiova and diagnosed with CF, the most majority were males, the male/female ratio being $3: 1$, which clearly shows a male genetic predisposition to this disease, an aspect which has been also highlighted by the specialists [13]. The average age of the investigated patients was $12.31 \pm 6.27$ years, with limits between four and 27 years [13]. The reported average age of the onset of the disease was $3.088 \pm 2.87$ months, with value limits of one day and seven months [14]. The onset symptoms of the disease were respiratory manifestations in four $(25 \%)$ patients, digestive symptoms and signs in six $(37.5 \%)$ patients or the association of wheezing with chronic diarrhea in four (25\%) patients, and the growth retardation with cough and diarrhea in two (12.5\%) patients [14]. The average age of the patients at the time of diagnosis of the disease was $3.63 \pm 2.72$ years, with limits in between zero and 12 years. The incidence of the main symptoms and clinical signs recorded in these children was cough in $12(75 \%)$ patients, expectoration in $10(62.5 \%)$ patients, dyspnea in eight $(50 \%)$ patients, wheezing in eight $(50 \%)$ patients, diarrhea in 10 $(62.5 \%)$ patients, loss of appetite in eight $(50 \%)$ patients, growth retardation in $12(75 \%)$ patients, abdominal pain in six $(37.5 \%)$ patients, postural hypotrophy in $16(100 \%)$ patients, pallor in six $(37.5 \%)$ patients, cyanosis in four $(25 \%)$ patients, persistent skin fold in eight $(50 \%)$ patients, mucosal dryness in eight $(50 \%)$ patients, bronchial rales in four $(25 \%)$ patients, tachycardia in eight $(50 \%)$ patients, abdominal distension in $10(62.5 \%)$ patients and hepatomegaly in four $(25 \%)$ patients.

Iontophoresis (sweat test) was the basic exploration for the diagnosis of mucoviscidosis. All patients presented sweat $\mathrm{Cl}^{-}$concentration values of over $60 \mathrm{mmol} / \mathrm{L}$, the average value recorded in these patients being of $114.75 \pm$ $18.07 \mathrm{mmol} / \mathrm{L}$, with limits in between 80 and $193 \mathrm{mmol} / \mathrm{L}$ [3]. These results were in accordance with the genotyping tests, the patients showing genetic changes specific to this disease [15]. Genetic analysis performed in 14 patients revealed six allelic mutations, each patient analyzed had 
two different alleles on chromosome 7 q31.2 locus. The frequency of mutations found was: $\triangle F 508$ in $18(53.57 \%)$ situations, $N 1303 \mathrm{~K}$ mutation in four (14.28\%) situations, G85E mutation found in three (10.71\%) situations, $5 T$ polymorphism in one situation (7.14\%), deletion 394TT in one case $(3.57 \%)$, and deletion $2184 \mathrm{~A}$ in another situation (3.57\%), frequency similar to that found in a study conducted on 777 samples collected from patients [16]. Most patients, nine $(56.25 \%)$ patients, presented with a heterozygous status, while a homozygous status was identified in five $(31.25 \%)$ patients. In our study, in two $(12.5 \%)$ patients who did not undergo genetic testing, the sweat test was used to help diagnose CF.

Conventional chest radiographs are usually adequate to detect the salient radiographic features of $\mathrm{CF}$ and provide objective parameters for longitudinal disease progression [17]. On the radiographs, the earliest change is the accentuation of the pulmonary interstitium. Also, pulmonary hypertransparency is a change that occurs quite early. Changes in lung imaging are due to thickening of the bronchial walls by infiltration of the bronchial submucosa with lymphocytes and plasma cells. In many cases, recurrent pneumonia, cylindrical or cystic bronchiectasis and multiple small abscesses developed in the bronchiolar walls appear [18]. Advanced complications of CF are atelectasis, pneumothorax, pneumomediastinum, pulmonary hemorrhage, cardiomegaly, and dilation of the pulmonary artery with the appearance of radiographic signs of chronic pulmonary heart [17]. High-resolution computed tomography (HRCT) is more sensitive and secure than standard chest radiography in establishment the presence and severity of bronchiectasis and other parenchymal and airway changes in CF [17]. There are scoring systems using HRCT to assess bronchiectasis severity in CF. These systems rely on a subjective evaluation of the presence, extent, and severity of different lesions of the $\mathrm{CF}$, including bronchial wall thickening, bronchiectasis, mucous plugging, and emphysema [19]. Pulmonary function measurements showed low values of FVC less than $80 \%$ of the standard values calculated in three $(25 \%)$ patients, low values of FEV1 less than $80 \%$ of the standard values calculated in five $(41.66 \%)$ patients, low values of bronchial permeability index less than $70 \%$ in three $(25 \%)$ patients. The analysis of the values of the spirometric indices obtained at the pulmonary function tests allowed the description of the obstructive ventilatory dysfunction syndrome in three $(25 \%)$ patients and mixed in two $(12.5 \%)$ patients. The chronic bronchial infection (colonization) and a persistent inflammatory response leading to the appearance of progressive bronchiectasis and obstructive and restrictive lung disease [20]. The measurement of FEV1 by spirometry is currently the essential parameter for monitoring lung function, assessing its severity and progression [21]. Lung function tests play an important role in the management of CF patients of all ages. We must be aware of the reference values used for spirometry since according to the chosen one, the respiratory functional diagnosis can be variable [22]. The bacteriological examination of the pathological respiratory disorders should occur whenever the patients present an inflammatory process of the respiratory symptomatology (intense coughing, increasing thickness and quantity of sputa, which intermingles with mucopurulent matter, the occurrence or disappearance of dyspnea), considering the risk of pulmonary colonization of these patients, mainly with extremely pathogenic, antibiotic resistant stems. Early sustained therapy with antibiotics of respiratory infections contributed to the longevity of patients with $\mathrm{CF}$ [23].

The low hemoglobin values, found in seven $(43.75 \%)$ patients could be explained by malabsorption syndrome, acute or chronic infectious phenomena, immunological phenomena recorded in patients with hypergammaglobulinemia [24]. The increased values of erythrocyte sedimentation rate (ESR) recorded in $14(87.5 \%)$ children were the consequence of acute inflammatory processes caused by infection, which complicated the evolution of the disease of these patients, the highest values being observed in bacterial lung infections (pneumonia) [24]. High $\gamma$-globulin levels in two (12.5\%) patients suffering from CF can be explained via the chronic infectious disease, which can cause local immunological reaction followed by a systemic one from the immunity system. Under these circumstances, a larger number of immunological tests is needed in order to be able to exclude an autoimmune pathology or a simultaneous hematological one [25]. High levels of $\mathrm{pH}$ determined in four patients $(25 \%)$, associated with low levels of electrolytes in blood $\left(\mathrm{Na}^{+}\right.$and $\left.\mathrm{Cl}^{-}\right)$and high bicarbonate levels determined the suspicion and diagnosis of $\mathrm{CF}$, based on hypochloremic and hyponatremic metabolic alkalosis, mainly in patients who, at the debut, presented episodes of diarrhea associated with dehydration with hydroelectrolytic imbalance and acid-base disorders [26]. Low levels of partial pressure of oxygen ( $\mathrm{PaO} 2)$ in six (37.5\%) patients affected by advanced bronchopulmonary disease (especially those suffering from bronchiectasis) determined chronic hypoxemia as well as the risks it generates, which necessitates a plan completion for caring and treating these patients [27]. Low levels of partial pressure of carbon dioxide $(\mathrm{PaCO} 2)$ (hypocapnea) were present in those four $(25 \%)$ patients diagnosed with metabolic alkalosis, attributed to chronic diarrhea, which caused the suspicion and early diagnosis of CF. High levels of $\mathrm{PaCO} 2$ (hypercapnea) correctly defined the type of hypercapnic respiratory insufficiency manifested in two $(12.5 \%)$ of the hospitalized patients, with the occasion of infectious exacerbations of the chronic bronchopulmonary disease and helped to set up an appropriate treatment [28]. Unfortunately, this type of respiratory insufficiency which complicated the evolution of the disease in the deceased child could not be corrected and was noted down as the immediate cause of death. The biochemical evaluation of the myocardial function, by determining the serum $N$-terminal pro-brain natriuretic peptide (NTproBNP), is useful for early diagnosis of the contractile dysfunction of the right ventricular myocardium, when the completion of the therapeutic plan is indicated [29]. Renal functional exploration, along with an assessment of the water-electrolyte imbalance and acid-base disorders highlighted electrolyte imbalances in patients manifesting dehydration, eight $(50 \%)$ patients and the one suffering from acute pyelonephritis in one $(6.25 \%)$ patient, which allowed the implementation of a correct therapeutic 
approach. The functional exploration of the liver, which was of major importance in these patients revealed biochemical modifications specific for cytolysis in five $(31.25 \%)$ patients and intrahepatic cholestasis in four $(25 \%)$ patients, pathological aspects common in such cases [30]. These modifications must be highlighted any time they appear, since in patients who are hospitalized for infectious exacerbations of mucoviscidosis and who need antibiotherapy, the antibacterial drugs must be chosen according to the level of hepatotoxicity. The evaluation of the exocrine pancreatic function was necessary both for the diagnosis of pancreatic insufficiency, but mostly for establishing an appropriate therapeutic care. In these patients, the medication for pancreatic substitution must replace the nutritional deficiency of patients, while it is acknowledged that proteincalorie malnutrition has its own supplementary contribution to the alteration of the pulmonary function [31]. Establishing the levels of albuminemia and oligoelements (calcium, iron, and magnesium blood levels) had a significant meaning in the therapeutic management of these patients, knowing that an early improvement in the manifestations of the syndrome of malabsorption will prevent metabolic and hematological disorders from occurring, since these had a negative impact on the evolution of the disease [25]. The investigation of the function of the endocrine pancreas is indicated by the glucose tolerance test, especially in patients with a history of prolonged pulmonary diseases. It is necessary and useful for the early diagnosis of diabetes associated with $\mathrm{CF}$, knowing that a delay in the introduction of the antidiabetic treatment will result in irreversible modifications at the level of small and large vessels [32].

$\mathrm{CF}$ is an autosomal recessive disorder with a varied penetrance and wide clinical variability. Interdisciplinary examinations were extremely important in these patients given the multisystemic nature of the disease, the role of the pediatrician being the most important, because he must recognize all the manifestations of the disease and request these examinations at the right time [33]. The neonatologist was requested whenever the newborn presented either respiratory distress at birth that required oxygen supply, or delayed appearance of meconium. The collaboration of the neonatologist with the pediatric surgeon was necessary and lifesaving in the case of newborns with meconium ileus, who did not respond to drug therapy or in the case of the newborn with jejunal atresia. In such cases, early indication for sweat test was beneficial to diagnose the disease since the first days of life [34]. ENT examination was indicated and provided useful information if the child had specific manifestations of acute adenoiditis, nasal polyposis, ethmoiditis, and acute/chronic sinusitis. These diseases required immediate performance of the sweat test and early diagnosis of this disease [35]. The pneumological examination helped establish the correct type and degree of respiratory failure and established, together with the pediatrician, the therapeutic conduct in the transition of childhood to adulthood [36]. Cardiological examination was required in all children diagnosed with $\mathrm{CF}$ who showed manifestations of severe respiratory failure and who were hospitalized for clinical and biological evaluation. It is necessary to develop a periodic cardiological exploration plan that allows the early detection of secondary pulmonary hypertension, which will indicate the establishment of new therapeutic measures particularly useful in preventing the installation of chronic pulmonary heart disease [37]. Periodic pediatric examination with clinical-biological evaluation will help for early diagnosis of malabsorption syndrome, establishing the degree of pancreatic damage by correct morphofunctional examination of the pancreas, early identification of hepatobiliary suffering and the establishment of appropriate hepatoprotective and anti-cholestatic therapy for this type of disease [38]. Urological examination in adulthood will be required whenever a young man with $\mathrm{CF}$ will want to start a family. Infertility induced by the absence of vas deferens can be overcome by intracytoplasmic injection of sperm after transcutaneous harvesting the sperm from the epididymis [39]. Neurological examination proved to be particularly necessary in agitated patients, in exacerbation of chronic respiratory failure, in whom hypoxic, but especially hypercapnic cerebral distress, required the exclusion of an organic neurological pathology [40]. Endocrinological examination was practiced in most children, given the endocrine and metabolic manifestations of malabsorption syndrome. The endocrinologist will establish the therapeutic conduct in girls who have delayed menarche, but especially the counseling of young man with azoospermia [41]. Psychological examination should not be missing from the exploration plan of these young patients, considering the special psychological problems that occur during the diagnosis of this chronic disease, and especially for the family of the patient in time of the transition of the patient to adulthood [42]. Genetic counseling is very important for families where one of the children has been diagnosed with $\mathrm{CF}$, or if a patient with $\mathrm{CF}$ wants to start a family [43]. Screening for carrier status and prenatal testing for pregnancies at increased risk are possible.

The HP examination highlighted the morphological substrate of the clinical and imaging manifestations of the patients investigated by us, emphasizing the existence of a correspondence between the imaging picture and the HP one. Most HP lung lesions detected by us in the child who died of CF were mucous cell hyperplasia, mucosal gland hypertrophy and acute and chronic inflammation of the lower respiratory tract. Changes such as bronchiectasis, atelectasis, emphysema, and pulmonary fibrosis are more the prerogative of older children and young people affected by this disease. Many authors have shown that the lungs are normal at birth [44], but that even before the infectious clinical picture became evident in the airways were observed: hypertrophy of the submucosal glands, obstruction of the excretory ducts, hyperplasia of mucous cells in the trachea and large bronchi and mucus hypersecretion [45]. In overt clinical forms of bronchiolitis, the airway lumen is filled with mucopurulent secretions and bacterial colonies, and the respiratory epithelium proliferates endoluminal as papillary projections. Over time, reinfections change the morphopathological picture to a chronic bronchial type with a mixed inflammatory infiltrate, which includes neutrophils and histiocytes, lymphocytes and plasma cells, and quite often is associated with follicular bronchiolitis 
[46]. The formation of endobronchial abscesses is the first step towards the development of bronchiectasis, their number increasing with age. They are more numerous in the proximal pulmonary airways, affecting especially the upper lobes, the middle lobe of the right lung, and the lower lobes $[45,46]$. In children, atelectatic lesions are also quite common, being the result of obstructive mucus plugs and lymphoid follicle hyperplasia adjacent to the bronchi [47]. In contrast, emphysematous lesions appear to develop at older ages, so that they become present in $41 \%$ of patients aged between $10-24$ years old [45]. At the same time, if in young children the HP picture is dominated by acute pneumonia, in the older children and youths the morphopathological picture is dominated by appearance of chronic inflammatory interstitial infiltrate, lymphocytes and plasma cell, interstitial fibrosis and the presence of lung cystic structures. It is discussed the existence of four types of pulmonary cystic structures developed in the CF evolution, respectively: $(i)$ bronchiectatic type, the most common, in which there is a direct communication with the bronchi, (ii) interstitial type, located in the visceral pleura and interlobular septa, frequently associated with pneumothorax, (iii) pneumatocele type, and (iv) emphysematous type [46]. In older patients, with the increase of bronchiectasis number, and as well as due to fibrous obliterative bronchiolitis, was noticed a decrease in the density of small airways [48]. At the same time, it seems that there is a prevalence of lesions such as pulmonary atelectasis, bronchial obliteration with mucus plugs and air cysts for the upper lung lobes $[49,50]$. Over time, pulmonary hypertension develops, due to the medial hypertrophy and intimal fibrosis of the pulmonary artery branches, which is often incriminated in the death of some of these patients due to rupture of dilated arteries and bronchial veins in the airway walls or bronchiectasis [51]. The severity of lung lesions increases with age, with emphysematous changes, pneumothorax, chronic pulmonary arterial hypertension, and severe chronic respiratory failure on the foreground [52]. Pulmonary amyloidosis with a diffuse interstitial pattern was also found in patients with a longer survival time [53].

\section{Conclusions}

The association of some phenotypic aspects specific for CF (recurrent pulmonary infections, MRSA or P. aeruginosa respiratory tract colonization, fat soluble vitamin malabsorption, the hyponatremic dehydration syndrome associated with hypochloremic metabolic alkalosis, or the connection between diarrhea and recurrent wheezing) with a positive result of the sweat test or the presence of the two pathological alleles made room for determining a positive diagnosis. The multisystemic character of $\mathrm{CF}$ requires a multidisciplinary approach to the problems of the patients involved in research, with a view to early diagnosis and guiding of the appropriate and timely treatment, which will alleviate and improve the quality of our lives and will increase life expectancy. A HP approach to this study revealed a connection between morphological characteristics of pulmonary lesions and the results of the imagistic investigations.

\section{Conflict of interests}

The authors declare that they have no conflict of interests.

\section{Acknowledgments}

Viorel Biciuşcă and Ileana Octavia Petrescu equally contributed to the manuscript.

\section{References}

[1] Davidson DJ, Porteous DJ. Genetics and pulmonary medicine. 1. The genetics of cystic fibrosis lung disease. Thorax, 1998, 53(5):389-397. https://doi.org/10.1136/thx.53.5.389 PMID: 9708232 PMCID: PMC1745224

[2] National Program of Cystic Fibrosis. Marius Nasta Institute of Pneumophthisiology, Bucharest, Romania, 2018, available from: https://marius-nasta.ro/programe-nationale-de-sanatate/ fibroza-chistica/ (in Romanian).

[3] Vankeerberghen A, Cuppens H, Cassiman JJ. The cystic fibrosis transmembrane conductance regulator: an intriguing protein with pleiotropic functions. J Cyst Fibros, 2002, 1(1): 13-29. https://doi.org/10.1016/s1569-1993(01)00003-0 PMID: 15463806

[4] Fung DCK, Rogers DF. Airway submucosal glands: physiology and pharmacology. In: Rogers DF, Lethem MI (eds). Airway mucus: basic mechanisms and clinical perspectives. Book Series: "Respiratory Pharmacology and Pharmacotherapy", Springer Nature, Basel, Switzerland, 1997, 179-210. https:// doi.org/10.1007/978-3-0348-8874-5_8

[5] Kulkarni H, Kansra S, Karande S. Cystic fibrosis revisited. J Postgrad Med, 2019, 65(4):193-196. https://doi.org/10.4103/ jpgm.JPGM_263_18 PMID: 31169132 PMCID: PMC6813676

[6] De Boeck K, Wilschanski M, Castellani C, Taylor C, Cuppens H, Dodge J, Sinaasappel M; Diagnostic Working Group. Cystic fibrosis: terminology and diagnostic algorithms. Thorax, 2006, 61(7):627-635. https://doi.org/10.1136/thx.2005.043539 PMID: 16384879 PMCID: PMC2104676

[7] John RM, De Dawn L. Respiratory disorders: cystic fibrosis. In: Maaks DG, Starr N, Brady M, Gaylord N, Driessnack M, Duderstadt K (eds). Burns' pediatric primary care. $7^{\text {th }}$ edition, Elsevier, St. Louis, Missouri, USA, 2020, 665-699.

[8] de Souza DAS, Faucz FR, Pereira-Ferrari L, Sotomaior VS, Raskin S. Congenital bilateral absence of the vas deferens as an atypical form of cystic fibrosis: reproductive implications and genetic counseling. Andrology, 2018, 6(1):127-135. https://doi.org/10.1111/andr.12450 PMID: 29216686 PMCID: PMC5745269

[9] Farrell PM, White TB, Ren CL, Hempstead SE, Accurso F, Derichs N, Howenstine M, McColley SA, Rock M, Rosenfeld M, Sermet-Gaudelus I, Southern KW, Marshall BC, Sosnay PR. Diagnosis of cystic fibrosis: consensus guidelines from the Cystic Fibrosis Foundation. J Pediatr, 2017, 181(Suppl):S4S15.e1. https://doi.org/10.1016/j.jpeds.2016.09.064

[10] Raina MA, Khan MS, Malik SA, Raina AH, Makhdoomi MJ, Bhat JI, Mudassar S. Assessment of correlation between sweat chloride levels and clinical features of cystic fibrosis patients. J Clin Diagn Res, 2016, 10(12):BC01-BC06. https://doi.org/ 10.7860/JCDR/2016/21526.8951 PMID: 28208841 PMCID: PMC5296414

[11] Schwartz KM, Pike-Buchanan LL, Muralidharan K, Redman JB, Wilson JA, Jarvis M, Cura MG, Pratt VM. Identification of cystic fibrosis variants by polymerase chain reaction/oligonucleotide ligation assay. J Mol Diagn, 2009, 11(3):211-215. https://doi. org/10.2353/jmoldx.2009.080106 PMID: 19324992 PMCID: PMC2671338

[12] Chillón M, Casals T, Mercier B, Bassas L, Lissens W, Silber S, Romey MC, Ruiz-Romero J, Verlingue C, Claustres M, Nunes V, Férec $C$, Estivill $X$. Mutations in the cystic fibrosis gene in patients with congenital absence of the vas deferens. $\mathrm{N}$ Engl J Med, 1995, 332(22):1475-1480. https://doi.org/10.1056/ NEJM199506013322204 PMID: 7739684

[13] Florescu L, Paduraru DTA, Mîndru DE, Temneanu OR, Petrariu FD, Matei MC. Epidemiological evaluation regarding the role of cystic fibrosis as a risk factor for child malnutrition. Rev Med Chir Soc Med Nat lasi, 2014, 118(2):450-456. PMID: 25076714 
[14] Sharma GD, Haver K. At what age is cystic fibrosis (CF) typically diagnosed? Medscape Intern Med, 2019 Oct 22, available from: https://www.medscape.com/answers/1001602-31227/atwhat-age-is-cystic-fibrosis-cf-typically-diagnosed.

[15] Kerem B, Rommens JM, Buchanan JA, Markiewicz D, Cox TK, Chakravarti A, Buchwald M, Tsui LC. Identification of the cystic fibrosis gene: genetic analysis. Science, 1989, 245(4922): 1073-1080. https://doi.org/10.1126/science.2570460 PMID: 2570460

[16] Al-Abadi B, Al-Hiary M, Khasawneh R, Al-Momani A, BaniSalameh A, Al-Saeidat S, Al-Khlaifat A, Aboalsondos $O$. Cystic fibrosis gene mutation frequency among a group of suspected children in King Hussein Medical Center. Med Arch, 2019, 73(2):118-120. https://doi.org/10.5455/medarh.2019.73. 118-120 PMID: 31391700 PMCID: PMC6643337

[17] Grum CM, Lynch JP 3rd. Chest radiographic findings in cystic fibrosis. Semin Respir Infect, 1992, 7(3):193-209. PMID: 1475543

[18] Pană I, Vlădăreanu M. Radiologie. Aparatul respirator. Ed. Didactică şi Pedagogică, Bucureşti, 1983, 246 (in Romanian).

[19] Calder AD, Bush A, Brody AS, Owens CM. Scoring of chest CT in children with cystic fibrosis: state of the art. Pediatr Radiol, 2014, 44(12):1496-1506. https://doi.org/10.1007/s00 247-013-2867-y PMID: 25164326

[20] Flume PA, O'Sullivan BP, Robinson KA, Goss CH, Mogayzel PJ Jr, Willey-Courand DB, Bujan J, Finder J, Lester M, Quittell L, Rosenblatt R, Vender RL, Hazle L, Sabadosa K, Marshall B Cystic Fibrosis Foundation, Pulmonary Therapies Committee. Cystic fibrosis pulmonary guidelines: chronic medications for maintenance of lung health. Am J Respir Crit Care Med, 2007, 176(10):957-969. https://doi.org/10.1164/rccm.200705-664OC PMID: 17761616

[21] Taylor-Robinson D, Whitehead M, Diderichsen F, Olesen HV, Pressler T, Smyth RL, Diggle P. Understanding the natural progression in \%FEV1 decline in patients with cystic fibrosis: a longitudinal study. Thorax, 2012, 67(10):860-866. https://doi. org/10.1136/thoraxjnl-2011-200953 PMID: 22555277 PMCID: PMC3446776

[22] Pezoa A, Jorquera P, Madrid R, Maturana P, Viviani P, Caussade $S$. Caracterización espirométrica de pacientes con fibrosis quística [Spirometric caracterization of cystic fibrosis patients]. Rev Chil Pediatr, 2018, 89(3):332-338. https://doi. org/10.4067/S0370-41062018005000303 PMID: 29999138

[23] Emerson J, Rosenfeld M, McNamara S, Ramsey B, Gibson RL. Pseudomonas aeruginosa and other predictors of mortality and morbidity in young children with cystic fibrosis. Pediatr Pulmonol, 2002, 34(2):91-100. https://doi.org/10.1002/ppul. 10127 PMID: 12112774

[24] von Drygalski A, Biller J. Anemia in cystic fibrosis: incidence, mechanisms, and association with pulmonary function and vitamin deficiency. Nutr Clin Pract, 2008, 23(5):557-563. https://doi.org/10.1177/0884533608323426 PMID: 18849562

[25] Jaffé A, Buchdahl R, Bush A, Balfour-Lynn IM. Are annual blood tests in preschool cystic fibrosis patients worthwhile? Arch Dis Child, 2020, 87(6):518-520. https://doi.org/10.1136/ adc.87.6.518 PMID: 12456552 PMCID: PMC1755836

[26] Sheikh HS, Tiangco ND, Harrell C, Vender RL. Severe hypercapnia in critically ill adult cystic fibrosis patients. J Clin Med Res, 2011, 3(5):209-212. https://doi.org/10.4021/jocmr612w PMID: 22383907 PMCID: PMC3279481

[27] Urquhart D, Montgomery H, Jaffé A. Assessment of hypoxia in children with cystic fibrosis. Arch Dis Child, 2005, 90(11): 1138-1143. https://doi.org/10.1136/adc.2005.071795 PMID: 16243867 PMCID: PMC1720198

[28] Bates CM, Baum M, Quigley R. Cystic fibrosis presenting with hypokalemia and metabolic alkalosis in a previously healthy adolescent. J Am Soc Nephrol, 1997, 8(2):352-355. PMID: 9048354

[29] Welisch E, Norozi K, Rauch R. N-terminal pro-brain natriuretic peptide level as a screening tool for cardiac involvement in paediatric diseases of extracardiac origin. Clin Res Cardiol, 2011, 100(9):723-730. https://doi.org/10.1007/s00392-0110317-0 PMID: 21487941

[30] Kobelska-Dubiel N, Klincewicz B, Cichy W. Liver disease in cystic fibrosis. Prz Gastroenterol, 2014, 9(3):136-141. https:// doi.org/10.5114/pg.2014.43574 PMID: 25097709 PMCID: PMC4110359
[31] Wilschanski M, Novak I. The cystic fibrosis of exocrine pancreas. Cold Spring Harb Perspect Med, 2013, 3(5):a009746. https:// doi.org/10.1101/cshperspect.a009746 PMID: 23637307 PMCID: PMC3633181

[32] Moran A, Brunzell C, Cohen RC, Katz M, Marshall BC, Onady G, Robinson KA, Sabadosa KA, Stecenko A, Slovis B; CFRD Guidelines Committee. Clinical care guidelines for cystic fibrosisrelated diabetes: a position statement of the American Diabetes Association and a clinical practice guideline of the Cystic Fibrosis Foundation, endorsed by the Pediatric Endocrine Society. Diabetes Care, 2010, 33(12):2697-2708. https://doi.org/ 10.2337/dc10-1768 PMID: 21115772 PMCID: PMC2992215

[33] Grosse SD, Boyle CA, Botkin JR, Comeau AM, Kharrazi M, Rosenfeld M, Wilfond BS; CDC. Newborn screening for cystic fibrosis: evaluation of benefits and risks and recommendations for state newborn screening programs. MMWR Recomm Rep, 2004, 53(RR-13):1-36. PMID: 15483524

[34] Siersma CL, Rottier BL, Hulscher JB, Bouman K, van Stuijvenberg M. Jejunoileal atresia and cystic fibrosis: don't miss it. BMC Res Notes, 2012, 5(1):677. https://doi.org/10. 1186/1756-0500-5-677 PMID: 23217263 PMCID: PMC3532316

[35] van King VB. Upper respiratory disease, sinusitis, and polyposis. Clin Rev Allergy, 1991, 9(1-2):143. https://doi.org/10.1007/ BF02914539 PMID: 1884322

[36] Okumura MJ, Ong T, Dawson D, Nielson D, Lewis N, Richards M, Brindis CD, Kleinhenz ME. Improving transition from paediatric to adult cystic fibrosis care: programme implementation and evaluation. BMJ Qual Saf, 2014, 23(Suppl 1):i64-i72. https:// doi.org/10.1136/bmjqs-2013-002364 PMID: 24415776 PMCID: PMC4449274

[37] Labombarda F, Saloux E, Brouard J, Bergot E, Milliez P. Heart involvement in cystic fibrosis: a specific cystic fibrosisrelated myocardial changes? Respir Med, 2016, 118:31-38. https://doi.org/10.1016/j.rmed.2016.07.011 PMID: 27578468

[38] Rowland M, Gallagher CG, O'Laoide R, Canny G, Broderick A, Hayes R, Greally P, Slattery D, Daly L, Durie P, Bourke B. Outcome in cystic fibrosis liver disease. Am J Gastroenterol, 2011, 106(1):104-109. https://doi.org/10.1038/ajg.2010.316 PMID: 20736939

[39] Lewis-Jones DI, Gazvani MR, Mountford R. Cystic fibrosis in infertility: screening before assisted reproduction: opinion. Hum Reprod, 2000, 15(11):2415-2417. https://doi.org/10.1093/hum rep/15.11.2415 PMID: 11056144

[40] Ellis S, Rang C, Kotsimbos T, Keating D, Finlayson F, Stark R, Thyagarajan D, Wilson J. CNS imaging studies in cystic fibrosis patients presenting with sudden neurological events. BMJ Open Respir Res, 2019, 6(1):e000456. https://doi.org/10.1136/bmj resp-2019-000456 PMID: 31423315 PMCID: PMC6688669

[41] Neinstein LS, Stewart D, Wang Cl, Johnson I. Menstrual dysfunction in cystic fibrosis. J Adolesc Health Care, 1983, 4(3):153-157. https://doi.org/10.1016/s0197-0070(83)80367-2 PMID: 6629971

[42] Goldbeck L, Besier T, Hinz A, Singer S, Quittner AL; TIDES Group. Prevalence of symptoms of anxiety and depression in German patients with cystic fibrosis. Chest, 2010, 138(4):929936. https://doi.org/10.1378/chest.09-2940 PMID: 20472857

[43] Moskowitz SM, Chmiel JF, Sternen DL, Cheng E, Gibson RL, Marshall SG, Cutting GR. Clinical practice and genetic counseling for cystic fibrosis and CFTR-related disorders. Genet Med, 2008, 10(12):851-868. https://doi.org/10.1097/GIM.0b013e3 1818e55a2 PMID: 19092437 PMCID: PMC2810953

[44] Zuelzer WW, Newton WA Jr. The pathogenesis of fibrocystic disease of the pancreas; a study of 36 cases with special reference to pulmonary lesions. Pediatrics, 1949, 4(1):53-69. PMID: 18146464

[45] Sheppard MN, Nicholson AG. The pathology of cystic fibrosis. Curr Diagn Pathol, 2002, 8(1):50-59. https://doi.org/10.1054/ cdip. 2001.0088

[46] Bedrossian CW, Greenberg SD, Singer DB, Hansen JJ, Rosenberg HS. The lung in cystic fibrosis. A quantitative study including prevalence of pathologic findings among different age groups. Hum Pathol, 1976, 7(2):195-204. https://doi.org/ 10.1016/s0046-8177(76)80023-8 PMID: 1262016

[47] Di Sant'Agnese PA. Bronchial obstruction with lobar atelectasis and emphysema in cystic fibrosis of the pancreas. Pediatrics, 1953, 12(2):178-190. PMID: 13088190

[48] Hamutcu R, Rowland JM, Horn MV, Kaminsky C, MacLaughlin EF, Starnes VA, Woo MS. Clinical findings and lung pathology in 
children with cystic fibrosis. Am J Respir Crit Care Med, 2002, 165(8):1172-1175. https://doi.org/10.1164/ajrccm.165.8.210 4090 PMID: 11956063

[49] Tomashefski JF Jr, Bruce M, Stern RC, Dearborn DG, Dahms B. Pulmonary air cysts in cystic fibrosis: relation of pathologic features to radiologic findings and history of pneumothorax. Hum Pathol, 1985, 16(3):253-261. https://doi.org/10.1016/s0 046-8177(85)80011-3 PMID: 3972405

[50] Waring WW, Brunt $\mathrm{CH}$, Hilman BC. Mucoid impaction of the bronchi in cystic fibrosis. Pediatrics, 1967, 39(2):166-175. PMID: 6017954
[51] Holsclaw DS, Grand RJ, Shwachman H. Massive hemoptysis in cystic fibrosis. J Pediatr, 1970, 76(6):829-838. https://doi.org/ 10.1016/s0022-3476(70)80362-6 PMID: 5444576

[52] Boat TF, di Sant'Agnese PA, Warwick WJ, Handwerger SA. Pneumothorax in cystic fibrosis. JAMA, 1969, 209(10):14981504. https://doi.org/10.1001/jama.1969.03160230032008 PMID: 5820106

[53] McGlennen RC, Burke BA, Dehner LP. Systemic amyloidosis complicating cystic fibrosis. A retrospective pathologic study. Arch Pathol Lab Med, 1986, 110(10):879-884. PMID: 2429633

\section{Corresponding authors}

Citto Iulian Taisescu, Associate Professor, MD, PhD, Department of Physiology, Faculty of Medicine, University of Medicine and Pharmacy of Craiova, 2 Petru Rareş Street, 200349 Craiova, Romania; Phone +40722-520 531, e-mail: taisescu@yahoo.com

Mihaela Amelia Dobrescu, Lecturer, MD, PhD, Department of Medical Genetics, Faculty of Medicine, University of Medicine and Pharmacy of Craiova, 2 Petru Rareş Street, 200349 Craiova, Romania; Phone +40741-194 395, e-mail: amelia_dobrescu@yahoo.com

Received: March 28, 2020

Accepted: December 19, 2020 